\title{
The Impact of Environmental Improvements on the Financial Performance of Leading Companies Listed in Bursa Malaysia
}

\author{
Tze San Ong, Boon Heng Teh, and Yee Woon Ang
}

\begin{abstract}
This paper analyses the relationship between environmental improvement and the financial performance of firms on a sample of 78 leading companies listed in Bursa Malaysia. This study uses content analysis to verify the extent of information disclosed and reported by companies. The results indicate that efforts to embrace environmental improvement and activities may help firms gain financially.
\end{abstract}

Index Terms-Environmental improvements, financial performance, Malaysia.

\section{INTRODUCTION}

An increasing awareness of the various environmental and social problems of stakeholders has led a shift in the way corporations and consumers go about their business routines. There has been a change in attitudes towards a greener lifestyle, and particularly to reducing negative impacts on the environment. Corporations need sustainable business practices in order to stay competitive.

To be sustainable is defined as to "meet the present's needs without compromising the ability of future generations to meet their own needs", as established by the World Commission on Environment and Development [1]. The commission is said to be the first major international effort to raise public awareness of the destructive effects of human activities on society and the environment and the risks in losing nature. The Commission has established a link between the economy, society, and the environment, and has shown that healthy social and environmental systems are required to sustain economic growth [2]. Thus, to be a sustainable organisation, engagement in sustainability development should be included in an organisation's future plans or as a strategy to maintain competitiveness. It concerns not only the quality of future global environment, but can also be viewed as a business opportunity and investment in the future so as to gain business competitive advantages [3].

The concept of sustainability involves everything from biology to business, and it overlaps with corporate social responsibility (CSR) not only in preserving natural resources,

Manuscript received April 7, 2014; revised July 19, 2014. The authors gratefully acknowledge the financial support of the Malaysian Ministry of Higher Education (Research Project 06-01-12-1105FR).

T. S. Ong is with the Department of Accounting and Finance, Faculty of Economics and Management, Universiti Putra Malaysia, 43400 Serdang, Selangor, Malaysia (e-mail: tzesan1108@gmail.com).

B. H. Teh is with the Faculty of Management, Multimedia University, Cyberjaya, Selangor, Malaysia (e-mail: bhteh@mmu.edu.my).

Y. W. Ang is with the Putra Business School, Universiti Putra Malaysia, 43400 Serdnag, Selangor, Malaysia (e-mail: angyw@gmail.com). but also focuses on future living standards. Sustainability has been a key issue for many corporations from "green" manufacturing to sustainability initiatives [4]. The challenge for corporations, however, is to find ways to close the gap between their stated sustainability principles and their actions towards long-term and short benefits [5].

According to a survey report from the Economist Intelligence Unit (2010) [6], which was based on over 200 senior executives in the areas of sustainability, corporate social responsibility and finance, $87 \%$ of the respondents agreed that sustainability will become more important over the next three years. $46 \%$ of those respondents agreed that sustainability represents a risk, but others see opportunity arising from sustainability. In this report, managerial executives have given their opinions on sustainability, such as Ming Long, CFO of Investa, a privately owned Australian real estate investment firm, who stated that sustainability practices could bring competitive advantages over other players; and Wim Bartels, the global head of Sustainability Services at KPMG in the Netherlands, who even predicted that some companies will disappear if they do not practice sustainability as part of their strategies. We can see from our results and the opinions of the senior executives the importance and attraction of sustainability to companies.

Sustainable actions can not only generate an organisation's revenue from new products, services and markets, but also control the cost for resource efficiency, build trust by enhancing brand value among stakeholders, and help organisations avoid safety and environmental incidents by complying with regulations [7]. For example, managing carbon emissions would link to cost reductions through increased resource efficiency. In addition, sustainability activities could also protect the reputation or enhancement of a corporate image, satisfy pressure from the community, consumers, and stakeholders, and fulfil societal expectations [3]. Reference [8] stated that the customer base of an individual business or industrial sector is greatly influential over the degree to which a company initiates sustainability activities.

The more organisations engage in sustainability development, the greater the competitive advantage gained in the industry. It must be noted that many leading companies such as Citigroup, GE have already foreseen the opportunities in implementing sustainability in their corporate strategy and this leading trend will later spread to other companies, even to the smaller companies and to other developing countries.

According to [9], companies that voluntarily adopt a sustainable business culture over many years have 
significantly outperformed their counterparts in terms of the stock market and accounting performance over the long term. Sustainability not only brings cost-related advantages and market advantages, it could also bring reputational advantages to organisations [10]. In September 2006, Bursa Malaysia brought out a CSR framework for public listed companies, which focused on areas in the environment, marketplace, community and workplace. Bursa Malaysia has always advocated CSR as being key to sustainability because sustainability supports stakeholder value creation, and the sustainability activities that integrate environmental and societal concerns into business strategies and performance could drive a superior operating performance and as a trademark of good management and corporate governance [11].

Most Malaysian companies have engaged in, or are performing, some level of sustainability activities, through meeting compliance requirements, volunteering for relief efforts, and donating money, amongst other things; however, the formal reporting of these sustainability activities is still very low. In addition, many companies are not actively engaged in corporate sustainability efforts due to their lack of understanding of sustainability. This passive involvement is also caused by a lack of empirical and convincing evidence about the benefits of sustainability development. This preliminary study therefore aims to investigate the relationship between environmental involvement and financial performance at corporate level.

\section{LITERATURE REVIEW}

\section{A. Environmental Sustainability}

According to [12], environmental sustainability was originally referred to as "environmentally responsible development" [13], then "environmentally sustainable development" [14], until most recently the environmental sustainability concept was developed [15], [16].

Reference [15] defined environmental sustainability as something that "seeks to improve human welfare by protecting the sources of raw materials used for human needs and ensuring that the sinks for human wastes are not exceeded, in order to prevent harm to humans". Reference [17] described it as "the ability to maintain the qualities that are valued in the physical environment". The Organisation for Economic Co-operation and Development, OECD (2001) defined environmental sustainability under four specific criteria: regeneration (renewable resources shall be used efficiently and their use shall not be permitted to exceed their long-term rates of natural regeneration), substitutability (non-renewable resources shall be used efficiently and their use limited to levels which can be offset by substitution by renewable resources or other forms of capital), assimilation (releases of hazardous or polluting substances to the environment shall not exceed its ability to assimilate, and avoiding irreversibility (irreversible adverse effects of human activities on ecosystems, biogeochemical, and hydrological cycles should be avoided).

The environmental dimension focuses on impacts on natural systems, such as land, water, air and ecosystems. It describes a company's effects on the physical environment that could be the most visible to consumers [15]. Examples include energy input, air emissions, greenhouse gas emissions, land and ecosystem use, incidence reporting, and regulatory compliance [4].

Environmental sustainability varies across an extensive range of organisations, "from heavily natural-resource-based organisations to banks and less natural-resource-intensive organisations" [18]. Some organisations may appoint environmental management consultants to carry out environmental assessments; while some organisations may have their own staff for such assessments. ISO 14001 Environmental Management System Standard may be a good framework to model an environmental assessment [18]. IMA proposed environmental performance indicators such as the selection of raw materials; creation of planned waste streams and unplanned waste and by-products; the impact of processes and indirect materials being used on employee health and the workplace; cost avoidance in areas such as the internal costs of managing toxic materials; reducing waste levels and other similar environmental aspects.

\section{B. Environmental Improvement and Financial Performance}

Reference [19] found a positive relationship between environmental improvement and the financial performance in US firms. One hundred and twenty-seven US firms were drawn from the Standard \& Poor's 500 Index (S\&P 500), engaged in the manufacturing, mining or production industries. The change in their emissions efficiency index (emissions per unit of output) for selected pollutants from 1988 to 1989 was regressed against return on sales (ROS), return on assets (ROA) and return on equity (ROE).

In a study of manufacturing firms in the S\&P 500, [20] also found the environmental performance (measured with the aggregate pounds of toxic chemicals emitted per dollar revenue of the firm and the number of environmental lawsuits pending against the firm) is both economically and statistically significant for the financial performance (calculated by using equation Tobin's $q$ ). Accordingly, poor environmental performance has a significantly negative effect on the intangible-asset value of firms.

Reference [21] analysed a sample of 337 Dutch and Chinese firms based on their communication of sustainability to employees and the origin country of the firms, using a binary logistic regression model. The authors found that there was a significant positive relationship between environmental sustainability and company performance, measured in profit and revenue development. A firm's policy on the re-usage of materials is positively correlated to profit development, while a firm's policy on the reduction of pollution is positively correlated to revenue development.

Reference [22] inferred a positive relationship between environmental performance (using environmental ratings expressed in FDRC, via the degree of compliances, expenditures, and reductions) and ROA in their study of 243 U.S. firms using regression analysis.

Numerous studies, however, have found that environmental performance is negatively linked to financial performance. Reference [23] suggested that there is a 
negative link between environmental performance and financial performance. Their study focused on 13 firms in the US pulp and paper sector and used data from 1978. The environmental performance indicator used was an emissions intensity index pollutant/ton of production calculated separately for Biochemical Oxygen Demand (BOD), Total Suspended Solids (TSS), and $\mathrm{pH}$; while the financial indicators used were net income, ROA, cash flow/equity ratio and cash flow/assets ratio.

In the study of [24] which was based on Toxic Release Inventory (TRI) data from 523 US firms, found that more recycling would lead to worse earnings-per-share growth. In short, there is a negative relationship between environmental sustainability and financial performance. In a study of 37 European paper industries, [25] established a negative relationship between the environmental and financial performance.

Apart from the results above, various studies suggest there is no significant relationship between environmental sustainability and financial performance. A study analysed 25 European companies from various sectors for financial performance indicators (ROA, ROE and earnings per share) and environmental variables $\left(\mathrm{CO}_{2}\right.$ emissions, energy consumption, water consumption, and waste disposal), and found that there was no significant positive or negative relationship between the financial variables and any of the environmental variables. Reference [26] also found that there is no significant relationship between environmental sustainability and financial performance in the context of food industries in the UK and France. The environmental measurement was the total amount of organic carbon emitted and the financial performance measurements were sales, ROI, and ROE.

\section{Methodology}

\section{A. Data and Sample}

The study sample of 78 listed companies was drawn from the top 100 companies, based on their market capitalisation, listed on the stock exchange of Malaysia, Bursa Malaysia, as at $27^{\text {th }}$ of May, 2013. The top 100 companies were selected for this study due to the expectation that they would have more advanced information on the sustainability reporting. The study covers a period of 5 years, from 2008 to 2012. Although this population is clearly biased towards the largest firms, this was not deemed to be a problem as there was ample evidence that environmental performance varies considerably among the largest firms. The main source of information was based on annual reports and sustainability reports from the respective companies listed in Bursa Malaysia.

\section{B. Variables}

According to [4], one key non-financial metric is the ability to meet sustainability needs without harming the ability of future generations to meet those same needs. Hence, the independent variables in this study are environmental performance aspects, which are guided by Global Reporting Initiatives [27] guidelines. While assessing organisational outcomes, financial performance is only one element in determining a firm's effectiveness [28], [29], and multiple measures may be required to evaluate overall corporate performance. The dependent variable is therefore financial performance, which is measured by ROA and ROE ratios.

\section{Environmental Improvement Aspects}

In this study, there are four groups of environmental improvements and activities, as below:

E1: Materials, Energy, and Water;

E2: Biodiversity;

E3: Emissions, Effluents, and Waste; and

E4: Others (Products and services, Compliance, Transport, and Overall)

\section{Return on Total Assets (ROA)}

The return on total assets (ROA) measures the overall effectiveness of management in generating profits with their available assets. The higher the firm's return on total assets, the better the firm is. ROA is calculated as:

\section{Earnings available for common stakeholders Total assets}

\section{E. Return on Equity (ROE)}

Return on Equity (ROE) is a measure of overall firm performance. It compares net profit after taxes (minus preferred stock dividends, if any) to the equity that shareholders have invested in the firm, that is,

\section{Net profit after taxes}

Shareholders' equity

This ratio tells us the earning power of shareholder book value investments, and is frequently used in comparing two or more firms in one industry. A high return on equity often reflects the firm's acceptance of strong investment opportunities and effective expense management. However, if the firm has chosen to employ a level of debt that is high by industry standards, a high ROE might simply be the result of assuming excessive financial risk.

To investigate the return more fully, a Du Pont approach is therefore utilised. This approach breaks down into components as below.

\section{$\mathrm{ROE}=$ Net profit margin $\times$ Total assets turnover}

This Du Pont approach to ROE helps to explain "why" a firm's ROE is less or greater than the industry's ROE.

Hypotheses:

$\mathrm{H}_{01}$ : There is a significant relationship between environmental improvement and ROA

$\mathrm{H}_{02}$ : There is a significant relationship between environmental improvement and ROE

\section{RESUlts}

The 78 listed companies in 10 different sectors (shown in Table I), were studied through their annual reports, and 
sustainability reports. The trading/services sector accounted for the highest percentage in this study, that is $32.05 \%$, followed by plantations, consumer products and finance sections; which are more than $10 \%$; while others are more than $5 \%$, except for the hotel sector, which only accounted for $1.3 \%$.

TABLE I: TOTAL NUMBER OF COMPANIES FROM EACH SECTOR

\begin{tabular}{|l|l|l|}
\hline Sector & $\begin{array}{l}\text { Number } \\
\text { Companies }\end{array}$ & $\begin{array}{l}\text { Percentage } \\
(\mathbf{\%})\end{array}$ \\
\hline Construction & 5 & 6.40 \\
\hline Consumer Products & 11 & 14.10 \\
\hline Finance & 13 & 16.67 \\
\hline Hotel & 1 & 1.30 \\
\hline Industrial Products & 5 & 6.41 \\
\hline Infrastructure & 4 & 5.12 \\
\hline Plantation & 8 & 10.25 \\
\hline Properties & 6 & 7.70 \\
\hline Trading / Services & 25 & 32.05 \\
\hline Total & $\mathbf{7 8}$ & $\mathbf{1 0 0 . 0 0}$ \\
\hline
\end{tabular}

\section{A. Summary of Descriptive Statistics}

The results of the descriptive statistics for the variables are presented in Table II. From the descriptive analysis, the mean value for E1 (Materials, Energy and Water) is 157.37. This indicates that the average number of words written under variable E1 is 157.37 words, and so for the other variables.

As shown in Table II, the standard deviation for E1 is 319.23, and the variance is 101908.013. This is the dispersion for distribution of each E1 for the period of five years, and it also shows that E1 has a variation or spread of 319.23 in the normal distribution.

TABLE II: DESCRIPTIVE STATISTICS FOR THE VARIABLES

\begin{tabular}{|l|l|l|l|l|}
\hline Variables & Mean & Median & $\begin{array}{l}\text { Standard } \\
\text { Deviation }\end{array}$ & Variance \\
\hline ROA & 0.0785 & 0.0657 & 0.0888 & 0.008 \\
\hline ROE & 0.1723 & 0.1358 & 0.2767 & 0.077 \\
\hline E1 & 157.37 & 43.00 & 319.230 & 101908.013 \\
\hline E2 & 221.79 & 19.00 & 751.395 & 564593.853 \\
\hline E3 & 230.23 & 65.50 & 536.219 & 287531.305 \\
\hline E4 & 102.76 & 0.00 & 349.466 & 122126.225 \\
\hline
\end{tabular}

\section{B. Reliability Test}

All collected data has been subjected to a reliability test. The Cronbach's Alpha coefficient for all the independent variables is 0.792 , which is considered reliable with a relatively high degree of internal consistency (Table III).

\begin{tabular}{|c|c|c|c|c|}
\hline \multicolumn{1}{|c|}{ TABLE III: RELIABILITY TEST } \\
& $\begin{array}{c}\text { Scale } \\
\text { Mean if } \\
\text { item } \\
\text { Deleted }\end{array}$ & $\begin{array}{c}\text { Scale } \\
\text { Variance } \\
\text { if item } \\
\text { Deleted }\end{array}$ & $\begin{array}{c}\text { Corrected } \\
\text { item-Total } \\
\text { correlation }\end{array}$ & $\begin{array}{c}\text { Cronbach's } \\
\text { Alpha if } \\
\text { item Deleted }\end{array}$ \\
\hline E1 & 2713.40 & 1.391 & 0.706 & 0.771 \\
E2 & 2648.98 & 1.294 & 0.405 & 0.783 \\
E3 & 2640.54 & 1.293 & 0.641 & 0.758 \\
E4 & 2768.01 & 1.443 & 0.430 & 0.787 \\
\hline Cronbach's Alpha $=0.792$ No. of item $=4)$ \\
\hline
\end{tabular}

\section{Results of Multiple Regression Analysis}

\section{1) Relationship between environmental improvement and $R O A$}

When ROA is regressed against environmental performance indicators (based on Table IV), it produces an
F-Statistic value of 3.019, which indicates that the result is valid at the significance level of 0.05 . Three per cent of the variation in ROA is explained by the variation in all the independent variables as indicated by the R-squared. Among the four environmental performance indicators, only E1 and E4 have a significant relationship with ROA. Their p-values are respectively 0.004 and 0.011 which are lower than the significance level of 0.05 . The estimated coefficient of 0.0062 indicates that $\mathrm{E} 1$ is positively associated with ROA; while -0.0044 indicates that E4 is negatively associated with ROA. Therefore, we reject the null hypothesis and stated that there is a significant impact of E1 and E4 on ROA.

TABLE IV: REGRESSION ANALYSIS OF ENVIRONMENTAL PERFORMANCE

\begin{tabular}{|l|l|l|l|l|}
\hline & Estimate & Std. Error & $\mathrm{t}$ & Sig \\
\hline Intercept & 7.509388 & .496551 & 15.123 & .000 \\
E1 & .006159 & .002099 & 2.935 & .004 \\
$\mathrm{E} 2$ & -.001201 & .000969 & -1.240 & .216 \\
$\mathrm{E} 3$ & .000390 & .001740 & .224 & .823 \\
$\mathrm{E} 4$ & -.004389 & .001725 & -2.544 & .011 \\
\hline $\mathrm{R}^{2}=0.030 ;$ & \\
Adjusted $\mathrm{R}^{2}=0.020$ & $\mathrm{l}$ & \\
F-STAT $=3.019$ &
\end{tabular}

\section{2) Relationship between environmental performance and} $R O E$

In Table V, the F-Statistic shows the value of 3.298, indicating that the estimated regression is valid and is statistically significant at the significance level of 0.05 . The $\mathrm{R}$-squared is only at the value of 0.033 , which indicates a very weak relationship between such independent variables and ROE. The regression results show that E1 and E4 are significant at the level of 0.05. This implies that E1 and E4 can significantly affect corporate financial performance. E1 is positively correlated with ROE at the estimated coefficient of 0.0195, and E4 has negative relationship with ROE at the coefficient of -0.0108 . Thus, we reject the null hypothesis and state that E1 and E4 have an impact on ROE.

TABLE V: REGRESSION ANALYSIS OF ENVIRONMENTAL PERFORMANCE

\begin{tabular}{|l|l|l|l|l|}
\hline & Estimate & Std. Error & $\mathrm{t}$ & $\mathrm{Sig}$ \\
\hline Intercept & 15.619532 & 1.544578 & 10.112 & .000 \\
$\mathrm{E} 1$ & .019488 & .006528 & 2.985 & .003 \\
$\mathrm{E} 2$ & -.005408 & .003014 & -1.794 & .074 \\
$\mathrm{E} 3$ & .003733 & .005412 & .690 & .491 \\
$\mathrm{E} 4$ & -.010823 & .005366 & -2.017 & .044 \\
& & & & \\
\hline $\mathrm{R}^{2}=0.033 ;$ & & & \\
Adjusted $\mathrm{R}^{2}=0.023$ & & \\
F-STAT $=3.298$ &
\end{tabular}

\section{DISCUSSION AND CONCLUSION}

This study explores the impact of environmental improvement on the financial performance of publically listed companies in Malaysia. It also attempts to examine company awareness of sustainability reporting. The results of this study suggest that it does indeed benefit a company to be green. When environmental performance is individually regressed with financial performance, we found that materials, energy, and water (E1), other environmental aspects (E4), local communities (S3), and other social aspects (S4) have effects on both ROA and ROE. 
In this study, there is a positive correlation between efficiency used towards natural resources (E1) and financial performance (both ROA and ROE). This is mainly due to cost saving and reductions that would directly increase the profitability of the company. This is consistent with the research of [21], which stated that policies on materials reuse is positively related to profit development. When companies advocate material reuse, energy efficiency and water re-usage policies, which stress the reuse/recycling of input materials, reducing the consumption of energy, promoting energy saving, providing more renewable energy products, and recycling water sources, this in turn reduces the costs and increases the profitability of companies.

On the other hand, E4 was found to be negative predictor for ROA and ROE. This is a result of compliances that are required by environmental laws and regulations, which increase the cost of companies, and thus decrease their profit. When companies are mitigating the environmental impact of products and services, they may need a lot of research and development, which will subsequently increase expenses, and reduce the return on the assets and equities. However, our study is not consistent with that of [22].

As well as the variables that are significant to both ROA and ROE, there are variables that are not significant. Our results suggest that emissions, effluents and waste (E3) do not have a significant relationship with financial performance, which is not consistent with the study by [19] where a positive relationship between emissions reduction and ROA, and ROE was found. It stated that there would be an increase in corporate ROA and ROE after efforts to prevent pollution through emissions reduction within one to two years of initiation. A negative relationship between the emission index and financial performance was also found in studies by [23], [24]. However, our findings were consistent with those of a study by [26], where no significant relationship between emissions and financial performance was found.

Additionally, E2 found to be no significant relationship between ROA and ROE in this study. One possible reason could be due to the fact that the companies studied are not engaged in biodiversity activities. Environmental disclosures are still in a stage of immaturity because Bursa Malaysia's requirement for reporting corporate sustainability has only been effective since 2006 .

This study has added to the environmental reporting literature by providing empirical results from the perspective of Malaysian listed companies. The findings of the study show that Malaysia, as a developing country, reported the increasing number of environmental reporting over the past few years.

Although careful attention was given to the methods of data collection and analysis, there are many other factors that affect the financial performance of a firm, should also be acknowledge. In this study, we have only focused on the impact of environmental improvement on corporate financial performance, other macro-factors such as the economic conditions, business environmental factors and the like are not considered during the period of the study.

Since environmental activities are categorized into four variables in this study, perhaps future researchers could relate all the variables and the financial performance to see more in-depth relationships between them. Financial performance indicators such as the current ratio and other profitability ratios could be considered, rather than the variables studied in this research.

Future researchers may conduct studies starting from the year 2010 instead of considering earlier periods, because sustainability issues are still new to Malaysian companies, and the financial crises of 2008-2009 may affect study results. Furthermore, the sizes of market capitalization have to be identified so that strong correlations between the variables can be seen.

Finally, a cross-sectional analysis could also be conducted to examine the impact of social activities and environmental activities on corporate financial performance for different sectors of industry.

\section{ACKNOWLEDGEMENT}

The authors gratefully acknowledge the financial support of the Malaysian Ministry of Higher Education (Research Project 06-01-12-1105FR)

\section{REFERENCES}

[1] WCED, Our Common Future: Report of the World Commission for Environment and Development, Oxford University Press, Oxford, 1987.

[2] Certified General Accountants Association of Canada (CGA). (2005) Measuring up: A study on corporate sustainability reporting in Canada. [Online]. Available: http://www.cga-canada.org/en-ca/ResearchReports/ca_rep_2005-06_s ustainability.pdf

[3] D. M. Cowan, P. Dopart, T. Ferracini, J. Sahmel, K. Merryman, S. Gaffney, and D. J. Paustenbach, "A cross-sectional analysis of reported corporate environmental sustainability practices," Regulatory Toxicology and Pharmacology, vol. 58, pp. 524-538, 2010.

[4] A. Reilly and A. Weirup. (2012). Sustainability initiatives, social media activity, and organizational culture: An exploratory study. Journal of Sustainability and Green Business. [Online]. Available: http://www.aabri.com/manuscripts/10621.pdf

[5] C. Park, R. Whittier, and M. McElroy. (2009). CFO insights Sustainability: developing key performance indicators. Measuring sustainability is the bottom Line. [Online]. Available: http://www.deloitte.com/assets/Dcom-UnitedStates/Local\%20Assets/ Documents/ us_cfo_kpis\%20for\%20sustainability_Nov202009.pdf

[6] Economist Intelligence Unit. (2010). Managing for sustainability. [Online]. Available: http://graphics.eiu.com/upload/eb/Enel_Managing_for_sustainability_ WEB.pdf

[7] Accenture \& Chartered Institute of Management Accountants. (2011) Sustainability performance management: How CFOs can unlock value. [Online]. Available: http://www.accenture.com/SiteCollectionDocuments/PDF/AccentureSustainability-Performance-Management.pdf

[8] K. Dummett, "Drivers for corporate environmental responsibility (CER)," Environment, Development and Sustainability, vol. 8, pp. 375 $-389,2006$.

[9] R. G. Eccles, I. Ioannou, and G. Serafeim, "The impact of corporate sustainability on organizational processes and performance," Working Paper 12-035: Harvard Business School, 2013.

[10] M. G. Gran, "Financial incentives for improved sustainability performance: The business case and the sustainability dividend," A Report Commissioned by the Mining, Minerals and Sustainable Development, United Kingdom, 2002.

[11] Bursa Malaysia. (2012). Sustainability. [Online]. Available: http://www.bursamalaysia.com/market/listed-companies/sustainability /introduction/what-is-sustainability

[12] B. Moldan, S. Janouskova, and T. Hak, "How to understand and measure environmental sustainability: Indicators and targets," Indicators of Environmental Sustainability: From Concept to Applications, vol. 17. 
[13] World Bank (2012). [Online]. Available: http://web.worldbank.org/WBSITE/EXTERNAL/EXTABOUTUS/E XTANNREP/EXTANNREP2012/0,,menuPK:8784414 pagePK:6416 8427 piPK:64168435 theSitePK:8784409,00.html

[14] I. Serageldin and A. Streeter, "Valuing the environment: proceedings of the first annual conference on environmentally sustainable development," Environmentally Sustainable Development Proceedings Series No.2, The World Bank, Washington D.C, 1993.

[15] D. McGinn, "The greenest big companies in America," Newsweek, pp. 34-54, 2009.

[16] R. Goodland, "The concept of environmental sustainability," Annual Review of Ecology and Systematics, vol. 26, pp. 1-24, 1995.

[17] P. Sutton. (2008). A Perspective on environmental sustainability? Institute of Management Accountants (IMA). The Evolution of Accountability—Sustainability Reporting for Accountants. [Online] Available: http://www.nickshepherd.ca/pdf/SMA_Sustainability_063008.pdf

[18] S. L. Hart and G. Ahuja, "Does it pay to be green? An empirical examination of the relationship between emission reduction and firm performance," Business Strategy and the Environment, vol. 5, no. 1, pp. 30-37, 1996.

[19] S. Konar and M. A Cohen, "Does the market value environmental performance?" Review of Economics and Statistics, vol. 83, no. 2, pp. 281-289, 2001.

[20] S. Vijfvinkel, N. Bouman, and J. Hessels. (2011). Environmental sustainability and financial performance of SMEs. [Online]. Available: http://www.entrepreneurship-sme.eu/pdf-ez/H201101.pdf

[21] M. V. Russo and P. A. Fouts, "A resource-based perspective on corporate environmental performance and profitability," The Academy of Management Journal, vol. 40, no. 3, pp. 534-559, 1997.

[22] J. Jaggi, T. Bikki, and M. Freedman, "An Examination of the impact of pollution performance on economic and market performance: Pulp and Paper Firms," Journal of Business Finance \& Accounting, vol. 19, no. 5, pp. 697-713, 1992.

[23] J. J. Cordeiro and J. Sarkis, "Environmental proactivism and firm performance evidence from security analyst earnings forecasts," Business Strategy and the Environment, vol. 6, no. 2, pp. 104-114, 1997.

[24] M. Magner, "How to reconcile environmental and economic performance to improve corporate sustainability: Corporate environmental strategies in the european paper industry," Journal of Environmental Management, vol. 76, no. 2, pp. 105-118, 2005.
[25] J. A. Aragon-Correa and E. A. Rubio-Lopez, "proactive corporate environmental strategies, myths and misunderstandings," Long Range Planning, vol. 40, no. 3, pp. 357-381, 2007.

[26] Global Reporting Initiative (GRI). (2011). Sustainability Reporting

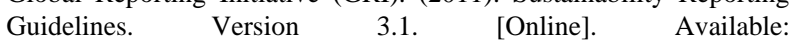
https://www.globalreporting.org/resourcelibrary/G3.1-Guidelines-Incl -Technical-Protocol.pdf

[27] R. M. Kanter, Supercorp: How Vanguard Companies Create Innovation, Profits, Growth, and Social Good, New York: Crown Business, 2009.

[28] P. Senge, B. Smith, N. Kruschwitz, J. Laur, and S. Schley, The Necessary Revolution: How Individuals and Organizations Are Working Together to Create A Sustainable World, New York: Doubleday, 2008.

[29] J. C. Nunnally, Psychometric Theory, 2nd ed. New York: McGraw-Hill, 1978, ch. 2, pp. 45-60.

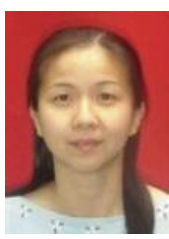

Tze San Ong is an associate professor at the Faculty of Economics and Management, Universiti Putra Malaysia. She holds a bachelor degree of accounting (Honours) and MBA degree from Universiti Putra Malaysia and earned her $\mathrm{PhD}$ degree from the Universiy of Leeds, UK.

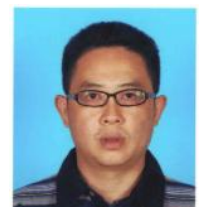

Boon Heng Teh is a senior lecturer and a PhD student at the Faculty of Management, Multimedia University, Malaysia. He holds a bachelor degree of accounting (Honours) from Universiti Putra Malaysia and master of international business degree from Leeds Metropolitan University, UK.

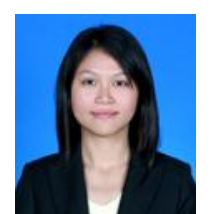

Yee Woon Ang is a PhD student at Universiti Putra Malaysia. She holds bachelor and master degrees in economics. 